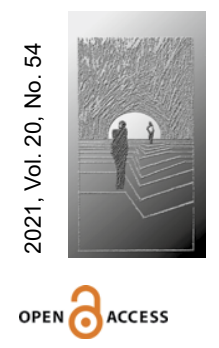

Edytorial:

\title{
Opieka i wychowanie w czasach kryzysu
}

Szanowni Państwo,

aktualny numer „Horyzontów Wychowania” poświęcony został szeroko ujętej problematyce opieki i wychowania w czasach kryzysu.

Opieka i wychowanie stanowią nieodłączne formy aktywności każdego człowieka, a szczególnie tego, który realizuje swoje życiowe powołanie w rodzinie. O opiece mówimy najczęściej w relacji rodzic - dziecko, dziecko - rodzic, opiekun - podopieczny, lekarz pacjent. Opieka niejednokrotnie powiązana jest z wychowaniem.

Obie formy aktywności ludzkiej - opieka i wychowanie - wymagają od osób je sprawujących wysiłku, wyrzeczeń, czasu, sił, środków finansowych i innych elementów niezbędnych do ich prawidłowego przebiegu. Sprzyjające warunki życiowe pomagają w wypełnianiu tych form aktywności ludzkiej, choć nie uwalniają od trudów nieodłącznie towarzyszących ich realizacji. Kiedy pojawia się nieplanowana sytuacja kryzysowa, trud związany z opieką nad drugim człowiekiem i wychowaniem dzieci wzmaga się, a niekiedy okazać się może ciężarem zbyt trudnym do uniesienia dla konkretnej osoby. Okoliczności stanowiące sytuacje kryzysowe dotknąć mogą jednostki lub całe społeczności, wspólnoty, społeczeństwa czy nawet cały świat.

W aktualnym numerze „Horyzontów Wychowania” znajdziecie Państwo artykuły dotyczące problematyki: analizy prawnoporównawczej porozwodowych porozumień rodzicielskich w przedmiocie opieki nad dzieckiem; prawa dziecka do relacji osobistej z rodzicami w sytuacji ich rozstania; roli rodziny w procesie rozwoju człowieczeństwa; edukacji zdalnej w czasie pandemii w perspektywie rodziców; metody nauczania online w kontekście postępu edukacyjnego i terapeutycznego dziecka ze specyficznymi trudnościami w uczeniu się; życia codziennego współczesnych matek - między oczekiwaniami społecznymi, poczuciem obowiązku a indywidualnym doświadczaniem macierzyństwa; prawodemii - rzeczywistości prawnej w dobie pandemii w Polsce; kryzysu migracyjnego i globalnego systemu zarządzania migracją w sytuacji pandemii COVID-19.

W imieniu Redakcji i własnym, życzę Państwu przyjemnej i owocnej lektury.

Marta Prucnal-Wójcik redaktor tematyczny numeru 